\title{
Investigating the Political Base of Indonesian Middle Class: A Comparative Study
}

Komunitas: International Journal of Indonesian Society and Culture 9(2) (2017): 267-282

DOI:10.15294/komunitas.v9i2.6273 (C) 2017 Semarang State University, Indonesia p-ISSN 2086 - 5465 | e-ISSN 2460-7320 http://journal.unnes.ac.id/nju/index.php/komunitas

\author{
Wasisto Raharjo Jati ${ }^{1}$ \\ ${ }^{1}$ Pusat Penelitian Politik - Lembaga Ilmu Pengetahuan Indonesia, Indonesia
}

Received: June 2016; Accepted: August 2017; Published: September 2017

\begin{abstract}
This article aims at analyzing the political base in the case of Indonesian middle class. It is essential to note that many multi-interpretation understandings to define terminology of Indonesian middle class. The definition of Indonesian middle class still undermines as "middle group" which is related to new rich people. Based on comparative analyzes, the emergence of Indonesia middle class have been separated with western middle class. In western case, middle class has possessed stable economic and politics material sources independently toward the state. The situation is what transforms the middle class as presser to the states and interest group. It can be said that both processes of the deepening of democratization and economic strength have been encouraged by middle class. In the Indonesian experience, it has been shown that Indonesian middle class keep up mutual relationship to the state. In other words, Indonesian middle class have entered elite power structure. However, in the current time, Indonesian middle class in postreformation era shows the emergence of political awareness to guard democracy justly. This article will elaborate deeply political basis of Indonesian middle class.
\end{abstract}

\section{Keywords}

middle class politics; political base; democracy; political power

\section{INTRODUCTION}

The terminology of the middle class in the socio-political study of Indonesia is a term that has not been finalized until now. Various kinds of academic explanations about the middle class have been widely shared and elaborated by many experts. However, various explanations only touch the surface level. A definite and detailed description of the definition on "middle class" remains unclear.

As for the case of the Indonesian middle class itself, the term is a fluctuating term. This is because the concept of the mid- dle class in the case of Indonesia is adapted to the context and events that follow. For example, the "Indonesian middle class" was once termed the middle class in the $1970-$ 1980 decade. But then in the mid-1980s, it changed to New Rich People (OKB) which lasted until 1998. The term "middle class" then reappeared in 2009-2010 to respond to the emergence of a consumptive Indonesian society in response to the economic

\footnotetext{
Corresponding author

Gedung Widya Graha, Lantai XI, Jalan Jend. Gatot

Subroto 10, Jakarta Selatan - 12710.

Email

wasisto.raharjo.jati@gmail.com
} 
growth of 6-7 percent.

In other words, the notion of the word "middle class" in Indonesia still merely refers to a consumptive class which is dependent with the state through its economic growth. The understanding of the dominant middle classes from economic-developmental science has obscured the concept of the middle class conceptually. The understanding and use of the middle class in literacy is solely a complementary part of macro analysis. However, it does not explain the middle class itself as a perspective framework. In the end, the understanding of the middle class is fixed on the notion of a consumptive class of society.

However, the notion does not explain authoritatively about the understanding of the Indonesian middle class in terms of social stratification and its political relations with the state. This paper aims to elaborate further on the interpretation of comparative political studies of Indonesian middle-class politics. The comparative study is chosen to explain the experience of the formation of the middle class, especially in the Western context with Indonesian context. Therefore, the theme line of the formation of the middle class in the case of Indonesia can be found and investigated.

\section{Middle Class in Classroom Analysis: Webberian and Marxian}

Class analysis is a classic study of political sociology by Max Webber and Karl Marx. Two thinkers represent two different styles of class analysis that differ from each other. Webber views class analysis from the perspective of differences of interest, while Marx views class analysis from the point of view of conflicting interests. Nevertheless, the two thinkers agree that they have not found the definite definition of the middle class. Both experts look at the class dichotomy relation based on the ownership of the means of production and the accumulation of capital as the factor of analysis. The middle class emerges as part of the class analysis trap, which is then understood in several important keywords as well as class consciousness, struggle, means of production, and political rationality.

The first is of which is awareness. States are placed as a contradictory entity between one another where there are classes competing to become ruler in the country. The key to being a ruler, in the end, refers to the awareness of the collective strength. As for being "aware" is of course intertwined with status and membership of a civic institution and other social institutions. That is because of the existence of a token of membership in which awareness itself is built on the processes of solidarity and other social capital. In this case, there are two basic key words in discussing, namely class for itself and class for in-self. The definition of class for in-self indicates that the awareness of being a class still experiences internalization. That is because it is not easy to unite various kinds of individual thoughts to get one whole mind. And, the class for itself means that the class has experienced externalization of value to be a contestant in an arena of power politics.

The second is the struggle. This conception is closely related to the political orientation that the class will embody in the political stage. It is then that distinguishes the political preferences of a class which can be distinguished whether it is advocative, artificial-temporary, or just based on the issue. It becomes important to see the understanding of the class in fighting for their aspirations. Marx is more inclined to see this struggle against the working class that is clearly and substantially oppressed by the bourgeoisie groups. However, that is not a consensus when it is contextualized to the present situation. The struggle is very inherent with the fulfillment of the articulation of the interests of the class to be achieved and to be implemented.

The third is the means of production. This means of production is a form rather than the identity of a class itself in contesting power. The more classes that have a monopoly over the means of production, it stands to reason that the class is what will be the ruler over the other groups. The condition happens as result of a strong in- 
terdependence factor in establishing interclass relationships which creates classes in a society: among main, ordinary, and the lower classes. It is this indicator of the means of production that becomes the technological determinism factor of a struggle.

The fourth factor is rationality which is related to the goal of political articulation to be achieved and realized in a class. This rationality is commonly formed because of ideology which is constructed into praxis of political movement. Or perhaps, this rationality itself is formed based on the development of artificial issues so it makes political rationality itself becomes unstable and ambiguous to follow. The existence of four factors that make the analysis of class politics in the realm of social sciences and political science becomes very pivotal and much talked about in various theories such as structuralism, functionalism, and ramifications of other theories which then form the classroom political theories and are developed into a very interdisciplinary discussion.

Of the four factors of class analysis, the middle class is actually in a conflicting space between state-society. This is related to the efforts of economic development and industrialization taking place with the emergence of three important actors namely the state as a regulator, the market as a distributor, and the community as an operator. And the development of the marketstate synergizes to try to subordinate to the community. Hence, from that point of fact, the root of the conflict occurs. In the very element of society itself, there are actually conflicts that occur in the analysis of Weber and Marx classes and represent the interests of the state-market or society.

From the perspective of Weber's analysis, the distinction of interest then spawns the great bourgeoisie, the petty bourgeoisie, the working class, the intellectual class, and the household class. The division of Weber is based on class situation faced by the people on the three following categories namely 1) procuring the goods, 2) gaining position in life, 3) self-satisfaction (Kivinen 1990, p. 105). In more detail, the category actually derives the derivative praxis from the three important prerequisites in looking at social stratification patterns in society, namely 1 ) lifestyle, 2) formal education, 3) occupation. In other words, Weber sees that social stratification is based on rationality as well as fulfillment of needs. In addition to those three key factors, the other thing worth noting is that the market. The middle-class analysis in Weberian's perspectives places the market as an important mechanism entity in constructing the construction as well as the class structure in society. The middle class is important to be discussed because of its plural character as both the bourgeoisie and the working class because of the variety of production tools it possesses. However, it is important to note that this Weberian thought is more directed to the development of capitalist society. Hence the meaning of the middle class is then placed in the context of the bourgeoisie society. Markets are an important arena in facilitating the different interests between different classes of society because they offer a fair mechanism for the exchange of services to each class member.

The context of the middle class in the Weberian is placed as petty bourgeoisies. This is because the petty bourgeoisie is a transitional class as well as the «between» the big bourgeoisie and the society. Another Weberian premise also says that beside it is only in the form of a petty bourgeoisie; another thing to note is that the middle class is representing the people's desire to take part in economic activities with ownership of the factors of production they have. The context of the having and having not classes is an important explanation in Weberian class analysis. The middle class is an important element in the development of industrialization of the country that focuses on the pattern of exchange of goods and services as well as diversification of production.

The middle class performs in multiple roles both as producer and consumer at the same time. The existence of multiple roles is a unique characteristic that is displayed by the middle class. This unique characteristic is built on the rationality in 
the middle-class work ethic. Of course, it is also related to the theological view that underlies the pattern and character. The middle class basically appears as an agency that links the interests of the state and society that has been cut off. Due to being an interest agent, this middle-class position is independent and neutral both from the state and the market. In other words, the middle class is a form of Western experience that people actually have political power due to their own rationality and capital power. The middle class plays an important role in regulating and changing the country's political landscape from the grassroots. As in the context of politics, the middle class is part of political structure that has three functions i.e., class, status and power (Ferreira 2012, p.30-31). As compared to other classes, the middle-class membership is diversification-based. Therefore, it enables the middle class to emerge as the largest class within society.

That is what makes the middle class can also be said as a class of political activities. The premise of no bourgeoisies no democracy becomes important to discuss to see middle-class carrier of democracy as a political movement. The various revolutions that took place such as the British Industrial Revolution, the French Revolution, the American Revolution of Independence, and so on were the result of the initiation of this middle class. If it is explained in more detail, the middle-class description of Weberian can be analyzed in the following table.

In contrast with Weber who views the middle class as a neutral or potential entity, Marx views the relation of the middle class as a relationship between the state and the society. The dimensions of the conflict can be derived in proletarian-bourgeoisie relations which are entirely grounded in the exploitation and dominance relationships (Dursun 2015, p.16). The nuances of the conflict are understandable because of the unfair market mechanisms of fair redistribution of welfare. The existence of the bourgeoisie and the proletariat emerges as a product of the market injustice. Class exploitation arises because the exchange of service-goods and means of production is only advantageous for the bourgeoisie class which has big capital rather than the proletarian class which has only a small portion of it. That is what makes the basis of Marx's analysis shows that the development of ca-

Table 1: Middle Class in Weberian View

\begin{tabular}{|c|c|c|c|c|}
\hline No & $\begin{array}{c}\text { Class } \\
\text { Parameters } \\
\text { in Weberian } \\
\end{array}$ & Explanation & $\begin{array}{l}\text { Middle Class } \\
\text { Values }\end{array}$ & $\begin{array}{l}\text { Middle Class } \\
\text { Form }\end{array}$ \\
\hline 1 & Class & $\begin{array}{l}\text { Although it says the middle class } \\
\text { is a class "in-between", but the } \\
\text { middle class is the entity class in } \\
\text { society because of the ownership } \\
\text { structure and material factors of } \\
\text { production. }\end{array}$ & Rationality & $\begin{array}{l}\text { The bourgeoisie } \\
\text { and working } \\
\text { class }\end{array}$ \\
\hline 2 & Status & $\begin{array}{l}\text { The middle class is a class that } \\
\text { has the same level of income and } \\
\text { expenditure. That is what drives } \\
\text { the middle class to try to excel } \\
\text { themselves. }\end{array}$ & $\begin{array}{l}\text { Materialism, } \\
\text { Festitism, He- } \\
\text { donism }\end{array}$ & $\begin{array}{l}\text { Leisure Class } \\
\text { and Pleasure } \\
\text { Class, New Con- } \\
\text { sumerism Class }\end{array}$ \\
\hline 3 & Party (power) & $\begin{array}{l}\text { The Middle Class has the potential } \\
\text { as a political class because it has a } \\
\text { large amount of mass compared to } \\
\text { other classes }\end{array}$ & $\begin{array}{l}\text { Democracy, } \\
\text { Voluntarism }\end{array}$ & Political Class \\
\hline
\end{tabular}

Source: Data is processed from various data 
pitalism is the continuous development of inequality.

The middle class, under the view of Marxian analysis, is in a dilemmatic space. In a way, Marx supports the middle class as part of the class revolution process because the middle class has the potential to move the greater masses due to the dominance of the working class and the lumpen proletarian class that could be maximized as a political movement. However, on the other hand, Marx rejects the presence of the middle class because of the characters of middle-class which is dependent and becomes a satellite for the great bourgeoisie. Instead, the middle class has the potential to become a new class of oppressors in the name of capitalist development and economic development in a fair and comprehensive way.

Therefore, in response to this dilemmatic position, the middle class in Weberian view is then placed in three important analyses. These three important analyses are useful to provide definitive explanations for the middle class. This is unlike the case with Weber which is still unclear in defining the middle class as "petty bourgeoisie". The elements of Marxian then look at the middle class into the three great understanding namely 1 ) the middle class as a class of new petty bourgeoisies, 2) the middle class as part of the development of new capitalist society, and 3) the middle class as part of fragmented class.

Understanding of the middle class as a class of new petty bourgeoisies cannot be separated from two important possibilities, namely 1) the middle class appears as an alternative economic development and 2) the middle class becomes the motor of transition of the proletariat towards the capitalist class. These two possibilities are inseparable from the membership of the "bourgeoisie" which varies in the middle class, such as from the bureaucracy, intellectuals, as well as other working classes. Marx basically gives no definite and obvious explanation on the meaning of the premise. But to reflect on the experience of the French, British, and German cases after the industrial revolution, for Marxian analysts, the middle class can be called as stabilizer class between the bourgeoisie and proletarian class conflicts because of the duality of the class function. Hence, this middle class position is actually within the sphere of political activism in which this class can rise to a great political mass whenever authoritarianism takes place. This is reflected in the case of a revolution in Britain demanding tax reform and representation, a revolution in the United States demanding independence and a revolution in Germany and France demanding democracy. This is the middle class that becomes the motors of a movement.

The refinement regarding to this perspective is then initiated by $\mathrm{Ni}$ cos Poulantzas in his two opus magnum namely Classes in Contemporary Capitalism and Political Power and Social Classes. In the first book, Poulantzas (1975, p.50) raises two important issues namely the formation of class awareness and the petty bourgeoisie in a phase of advanced capitalism. The class awareness in Poulantzas's own terminology is very different from Marx's understanding where class awareness is formed on the basis of the collectivity of oppression addressed by the bourgeoisie against the proletariat workers. The logic is then reversed by Poulantzas that awareness as a class itself is formed due to an objective awareness as a political agent. In this case, Poulantzas considers that the idea of class awareness is essentially contradictory and antagonistic in which the awareness cannot be denied as a communalism. Poulantzas looks at the free of will side which is shown by the awareness of a class as an objective entity. Self-class awareness is ultimately determined within a deterministic structural framework. The formation classes in a class level are not determined by mere economic resources which has been the basis for dividing the base class per se. however, we also see that the determinism of a class itself is also determined rather than just merely social and political forces. Therefore, what is meant by Poulantzas with free of will is the determinism driven by social capital of workers production that is constantly mo- 
ving rationally.

The discussion about the social mode of production of the working class is determined on the productivity and the mentality that they have as the main resources in conducting the production activities. The second premise is what makes the difference with Marx who views the economic base as the basic foundation in assembling class formation in society. In the Poulantzas analogy, it is mentioned that both social and political factors intertwine each other in determining class determinism in which class classification is determined by the mental and production represented by each class. Hence, the possession of the mental and the production becomes the key to seeing how appropriate and relevant a person is to the class of the proletariat and the bourgeoisie.

Regarding to the formation of the petty bourgeoisies which becomes the other locus in Poulantzas thinking, it is noted that the petty bourgeoisie is a form of transformation or transition of the working class to the bourgeoisie. Another thing that needs to be embodied in Poulantzas thinking is to distinguish the capital itself in two fundamental variables of function and place. Poulantzas sees that the ownership of capital into the mode of production in advanced capitalism itself is not inherently a major tool. In the phase of advanced capitalism, there is a disassociation pattern in society. This means that the possessive nature is shown in analyzing the actual ownership of capital. The capital is no longer important in analyzing the capital position of the petty bourgeoisie which should be determined by ideologies that accompany it such as advocacy, state fetishism and liberalism. It is this contribution of Poulantzas thinking which then becomes important to see the context of relative autonomy in the idea of postcolonial society. Poulantzas provides the context of the independence of a class in the understanding of relative autonomy as well as interdependence context in a class, especially in the relation of imperfect mode of production.

It is later seen in the other work of
Poulantzas (1975), Political Power in Social Classes, that there is relative autonomy of every class itself. The relative autonomy indicates some political forces which are potentially established and owned by every class of society to become mutual hegemony in the power structure. Hence, the field of power struggle in the arena of the superstructure of many powers is controlled by the contestation of competing class autonomy. The existence of such relative autonomy indicates the existence of the resources that each class has as its political bargaining power. This is what makes the interdependence context an important pattern in creating collective power relations.

The understanding of the middle class as a new capitalist class puts the middle class as part of the process of capital accumulation. The middle class is an important part of the economic development that the earlier capitalist class has done. Marx views this phenomenon in the case of the industrial revolution in Prussia where the emergence of the middle class with the various means of production it possesses emerges due to the variety of production equipment that makes industrialization work. In addition, another factor is the power of middleclass consumption that can absorb the production. Therefore, the flow of production and consumption circulation is the one that makes capitalism still exists.

The new understanding of the middle class as a new fragmented class is defined as middle class that forms the exclusive different classrooms case with the bourgeoisie and the proletariat. This middle class develops models, behaviors, and norms that distinguish them from both the proletariat and the bourgeoisie. As a fragmented class, the middle class cannot be the bourgeoisie class because of its diverse production tools so it does not reflect the strong middle class character. But they also cannot be a proletarian class because of the level of consumption and production is different from the proletarian class. This middle class develops a unique identity pattern that aims to identify themselves as a distinct class through a pattern of consumption that leads to more 
lifestyle and production. They are more concerned with image rather than quality. Middle-class fragmentation also occurs not only in the "dependent" conditions between the bourgeoisie and the proletarian class but also fragmentation is present in the internal middle class itself. Internally, the middle class is divided into three large classes: upper middle class, middle middle class and also lower middle class. Each of these middle-class characteristic displays the distinctive features. But clearly, the image and features displayed by the middle class are "false" because they do not succeed in becoming a bourgeoisie class or may descend into the proletarian class.

The condition of "artificiality" faced by the middle class from Wright (2009, p.102-105) in Understanding Class is mostly caused by the reading of the political class approaches which can be divided into three terms, namely class as attributive function in the perspective of structuralism, class as a function of social exclusion in hoarding prosperity, and class as a relationship of domination-exploitation. The first is the class as an attribute function which can be interpreted that the class is a manifestation of attributive material inherent in it. It means that in the formation of classes, the material function determines the classification of society in a particular class. The material intended in this context is not always the aspect of money income, but also the level of education and lifestyle become an important categorization in structuring the class. This is because the material serves as the identity of politics of a community. The lower class tends to have a low education level with low incomes as well. Middle class has a better level of education and has generated good income. Besides, their lifestyle tends to also follow the mainstream lifestyle patterns in accordance with the trendsetters offered by the capital market. The middle group is basically a class form of social proofing as imitators who have a tendency to be a follower on a number of issues. Therefore, it is not surprising that this class is actually included in the categorization of swing voters, who have a political trend which is still fragile so it is easy to be influenced by political preferences. The upper class is a class of educated people with excellent education and very well-established income. It is later implicated in their life style of jet set with all luxuries of life. The second perspective that class as its own arena of social exclusion can be analyzed as a dichotomous form between privileged and neglected in the social strata. This second perspective analysis is much inspired by Webberian thinking where social status and identity can actually be grasped from how deep the value of occupational asceticism it possesses in obtaining class establishment. It becomes an important premise and this second perspective is also often referred to as hoarding perspective. This is because there is an attempt to hoard the wealth of the working process results. That is what distinguishes the class from how much hard work they get and what they do. The conditions then create the social exclusion among which the class of privileged and neglected. The third perspective is about the class as a relation of domination-subordination relationship which is departed from the Marxist notion of class relations. The perspective assesses the relations of inequality and the existence of an uneven redistribution of income among classes. This situation then leads to a relationship of exploitation where ownership of the material becomes the key to the mastery of other classes.

Therefore, generally, the meaning of the middle class in terms of Marxian can be categorized into four major keywords namely the conflicting relationship between the market-state, internal conflict within the middle class society, as well as inequality-exploitation as the main problems. Aside from these two perspectives, the other theoretical alternative in reading the middle class is the perspective of structuralism. The perspective is almost the same with both macro perspectives that have existed before by placing the hierarchical relationship of the state-market-society as the main unit of analysis. However, it has a difference in terms of setting the relation. Structuralism views the relation of the middle class 
in the constellation of the societal-marketstate which can be both conflicting and collegial depending on the degree of participation of the middle class in economic activity. In other words, some important keywords such as capital, production, and commodity are also important keywords in the analysis. The middle class receives space and recognition depending on how active or passive it is seen in the communitymarket-community relations. The degree of liveliness and passivity can be seen from how the factors and means of production can be replicated. This is what then puts the middle class as a motor of economic movement, as well as in political issues. Hence, if it is described in tabulation form, the relation of middle class analysis based on these three perspectives can be described as follows Figure 1.

In discussing the relationships of the three domains, we can analyze different perspectives in analyzing the class. First, the analysis of the class itself departs from social relations in control of economic capital in the structure of society. It is later developed into a social exclusivism among other community classes. The existence of exclusivity is what later evolves into some premises such as the attributive nature of the economic capital, the relationship of domination-subordination, and the accentuation on market relations. The implication is the emergence of the pattern of conflict on the growing production in the Marxian analysis that emphasizes the dominationsubordination relationship. The conflicts over distribution in the Weberian analysis are based on the distribution patterns of economic capital itself, and the division of its economy is based on self-ability.

Based on those three great streams of thought performed by Wright, the analysis is deepened by Ronald H. Chilcote (1994) who later maps the ontology and epistemology into five streams in understanding the class political pluralism, instrumentalism, structuralism, criticalism, and statism and class competition.

Pluralism, looking at the context of political powers itself; it is divided into various scopes. The concept of redistribution of power is indeed departed from Plato who views the essence of democracy as a communal dominance. The classical theorists such as Jeremy Bentham and John Locke mostly mention about a pluralist democracy. Therefore, the power is spread apart from each other regarding the conception of classes that are related to pluralism. We can see that the power distribution is not equal to each other. Pluralism then develops into power of identity for each class that has the power resources. The elites evolve into a class that receives resources great power with ordinary people. Pareto itself divides the class in terms of class understanding of pluralism into several inter-

Figure 1. Political Comparative Analysis of Middle Class
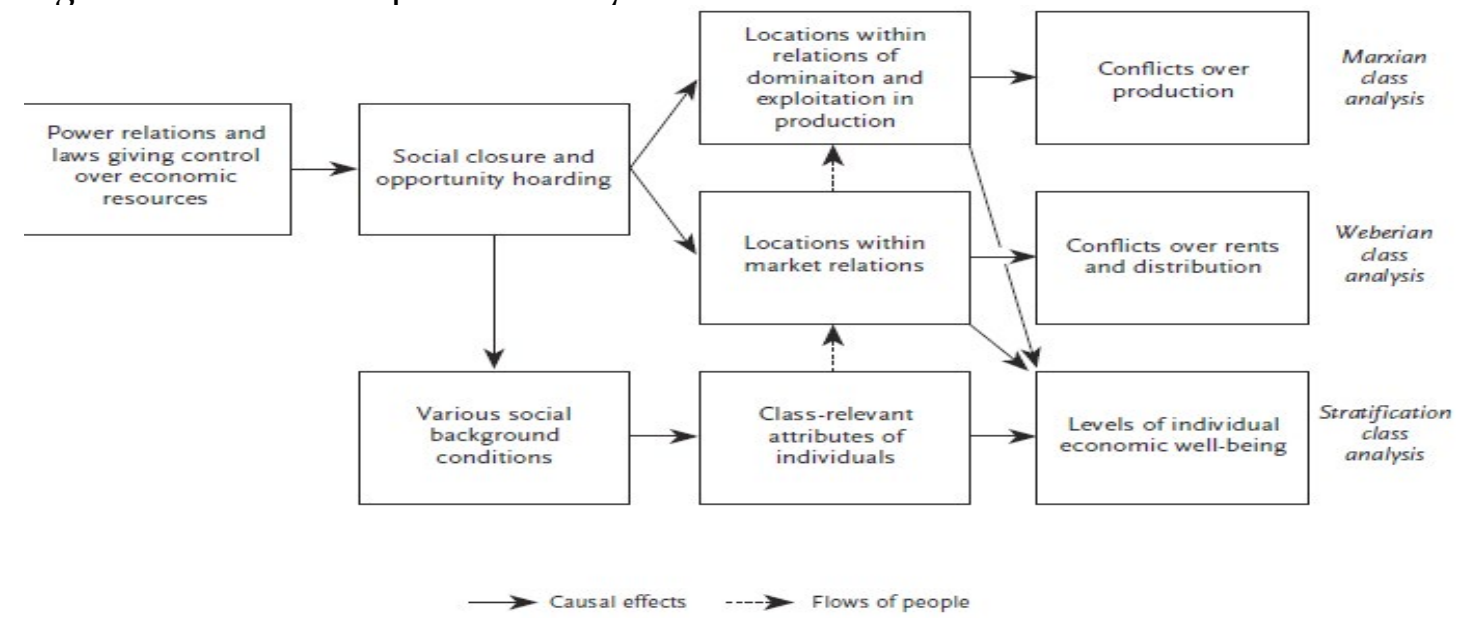

Source: (Wright 2009, p.116) 
est groups such as the governing elite, nongoverning elite, and interest groups. The accentuation in the context of the elite is based on how large and widespread the actual distribution of power is centralized and run. It then describes the operation of the power in the context of the class. This means that governing is basically explains how the conflict between the classes lasts in the context of the ruler in an arena of power.

Instrumentalism. Unlike the pluralist understanding that emphasizes the power which is decentralized and dispersed, the paradigm of instrumentalism itself tends to see that power as concentrated and centralized entity. The premise emerges considering their own states in the position as "executive committee that serves the interests of the country" (Burnham 2008, p.84). Therefore, the paradigm of instrumentalism itself emphasizes the context of the ruling class as a manifestation than the capitalist class which comprises the bourgeoisie who controls the policies and interests of the state. This is what distinguishes the plural which emphasizes to govern with instrumentalists which emphasizes to rule. This means that in a pluralist understanding, the process of contestation is balanced and dualism to be a ruler or administrator on other classes. Whereas, in the context of an instrumentalist, mastering capital becomes important to be a ruler on other classes.

Structuralism is in line with the opinion of instrumentalism which puts the state as critical entities and always keeps the interests of the capitalists than the public as a whole. This conception is developed by Poulantzas who views the two sides of the class in terms of both practice and conception. Relationships structure itself is developed in a contradictory relationship because the relationship between classes is constantly opposing each other. That is what makes the class relations arranged in a hierarchical building always creates relation paced classes of structuralism and also put their political orders from one class to another class. The order is a form of practices of class subjugation that has big capital with the class that has a weak capital. The emergence of orders is what leads to the practice of class exploitation becomes intensified when there is an economic resources competition.

Statism and Classes Competition refer to the understanding of political theory class which presupposes that the relationship between the actual class relationships is contradictory and competing. Due to the competitive nature of the class, they keep on competing and pushing their agendas into the state as an arena of contestation. Hence, the circulation of elite born of the contestation process always produces the resistance of the class below. Besides that, another context that needs to be seen in this perspective is the spirit of advocacy initiated by the class. Advocacy is closely related to the efforts undertaken by the articulation of the interests of lower classes with a class on it. Then, another dimension that needs to be understood is actually how the extra informal political movement based parliamentarian is driven and run by the community itself.

So, if it is analyzed and elaborated in further discussions on class politics, it can be described as a process of determinism to power. Determinism is intimately linked to how power is operationalized and contested by the class in the arena of power. A class is actually a product of historical determinism of social stratification which is executed and implemented by a system. Determinism is born from the process of economic capital contestation which is unbalanced so it creates a hierarchical relationship.

Although the discussion of class politics itself is dominated by the capital competition, another important thing which should also be discussed is the reason of rationalism and intellectualism formed by the class process. This rationalism is related to the preferences or political linkages which need to be displayed and demonstrated by the class strata in dealing with specific issues. If we look more elaborately, the function and position of the actual class is the agent of a democracy in a parliamentarian political level. The essence and spirit of street- 
level politics as well as street-level democracy shown by this class displays the spirit of advocacy and curative measures against certain issues. For example, we can see the movement of the working class in a revolution like in the case of workers' revolution in France in the 19th century that brought down the despotic regime, the labor movement of the Bolsheviks in Russia then established a government of the Soviets, the velvet revolution led by Vaclav Havel in the Solidarnosc movement to overthrow the government authoritarian in Czech, the movement of people power in the Philippines, to the World Social Forum movement every year agenda in Porto Alegre, Brazil. This means that every class in society itself has their own rationality and consciousness to be a massive informal political movement.

Another interesting point related the movement is a political rationality itself. Studies of class which is actually contradictory political fight puts rationality on class movement of lumpen proletariat. This means that in this context, the political rationality that is formed is anti-establishment and socially equitable redistribution. However, there is more rationality which needs to be further elaborated, especially in the formation of political awareness. If it is traced in the classical understanding of the awareness both of Marx and Poulantzas, the awareness is formed due to the collective feelings against the oppression and exploitation material. The classical understanding implies an existence of consolidative and collective strength which is designed ideologically. Therefore, when discussing the politics of class in the present context, it is actually located on advocacy issues and concentration as well as the articulation of interests that is needed to be run. This idea is what forms social-networking of corporatism in society.

However, we also need to understand that awareness is not always experiencing an sich. Other premises which need to be noted is whether or not it has a relative autonomy and independence in taking the state as an arena of power contestation. There is also an understanding of the class that in fact becomes dependent and servile state. Especially on the study of a class like this, it is influenced by the structure of the political economic development of the state. The growth of new classes is correlated with increasingly economic growth and income in a country. This means that this class grows with comfort zone facilitated by the countries with all kinds of other consumption growth. Classes that grow in such model will only be the class which is spoiled and does not want to undertake economic production. Though the class is actually created and grouped hierarchically by means of production under their control.

The existence of such a spoiled class is what will be a time bomb of its own for the country because they will arise due to the stagnation in economic growth and in the end, they will only be a thorn in the flesh. This class is also very apolitical to the development of renewable and political realms. They likely keep the contest of status quo against the current regime. They are not concerned with the characters of the regimes whether they are democratic or totalitarian as long as the state provides all kinds of goods and services that they need. This class will be the class material and economic rents who will never be satisfied with the service from the state and always demand more. Admittedly, the existence of this class is the motor of economic growth for the country as a whole. However, the design of this class is very weak.

The current political social analysis which views class studies, such as reviews Guy Standing (2011, p.10) in Precariat Society, mentions that when the economy is increasingly growing and developing rapidly and massively. Hence, what happens instead is the grouping of economic surplus controlled by a specific class group. It is later what makes the classes below it to be a class of subsistence. The emergence of the middle class as a new community group actually makes a serious threat to their lower group to be marginalized communities. The conditions of precariat (Vulnerability) are also affected by the world economic and political constellation after 2008, which 
Table 2.Typology of Class Division-Based of Political Orientation

\begin{tabular}{llll}
\hline No & \multicolumn{1}{c}{ Indicator } & \multicolumn{1}{c}{ Political class } & \multicolumn{1}{c}{ class apolitical } \\
\hline 1 & Political Orientation & Advocating & Conservatives \\
2 & Relations with the State & Independent & dependent \\
3 & Modes and Production Tools & Working class & Consumer class \\
4 & Class Base & $\begin{array}{l}\text { lumpen proletarians Class- } \\
\text { es and subsistence class }\end{array}$ & Middle and upper class \\
5 & Class Character & Solidarity-based collective & $\begin{array}{l}\text { Needs-based Individu- } \\
\text { alist }\end{array}$ \\
\hline
\end{tabular}

Source: compiled from various data

makes the condition of the world insecure. The emergence of insecurity is due to the economic turmoil that has not fully recovered and many people then become frustrated and depressed about the crisis such as the unemployment and loss of jobs in many countries. This insecurity could potentially result in chaos and turmoil if not resolved immediately. So, if it is traced further in two major terminologies, understanding the orientation classes themselves can be understood as follows.

\section{Context Political Studies Indonesian Middle Class: A Comparative Study}

The study of the political assessment of the Indonesian middle class can be assessed in two different lanes namely intellectual and academic track lanes. Both lanes are actually part of community development in colonialism. Both of these lanes are also the mechanism for forming new skilled and educated communities to support the activities of the administration and also the country's economy. The goal of the new community development is to generate professional community as well as the bureaucracy, academia, and also traders. The three groups occupy an important position in the structure of Indonesian society in the era of independence. The new society occupies a middle position between the government and the people simultaneously. Toward the government, this new society is a temporary development agency of the people. The position of this new society is an agent mediating the interests of the community. From there, the new community group commonly known as the new middle classes in Indonesian society is es-

tablished.

However, prior to the discussion of political studies at the Indonesian middle class, a comparative study of the development of the middle class needs to be contrasted with the construction of the middle class in the West. It becomes important to map out a comparative study of the politics of the Indonesian middle class. The western experience shows that the middle class is born from a process of economic development which then spreads out to the political problem. It can be seen from the emergence of the economics guild, as well as the principle of no taxation no representation, and also no bourgeoisies no democracy (Masoed 2006). Important premise that needs to be addressed is that the Western middle class is a class of feudal class transition towards the bourgeoisie. In other words, the transition also involves the production factor and transformation tools of the middle class which are developed to the mechanization of production tools.

By having such an independent position, middle class position in the West case has an independent position with the state. Hence, they are more critical and political toward the government. It can be seen from the formation of political parties in the West who fully represent the interests and ideological cleavage in every political party. Therefore, it is necessary to determine the basis of division which is not only based on Western and colonial state, but also the condition of pre-capitalism with the post-capitalism. Therefore, if it is further, the tabulation of explanation of comparative development of the middle class can be analyzed as follows Table 3 . 
Table 3.

\begin{tabular}{|c|c|c|c|}
\hline No & Parameter & Western Middle Class & $\begin{array}{l}\text { Middle Class in The Third World } \\
\text { Countries }\end{array}$ \\
\hline 1 & $\begin{array}{l}\text { Class Formation } \\
\text { Period }\end{array}$ & $\begin{array}{l}\text { Feudalism Transition Pe- } \\
\text { riod towards the Indus- } \\
\text { trialization }\end{array}$ & $\begin{array}{l}\text { Construction of the middle class } \\
\text { itself is initiated and nurtured by } \\
\text { state }\end{array}$ \\
\hline 2 & $\begin{array}{l}\text { Ownership of } \\
\text { Tools and Produc- } \\
\text { tion Factor }\end{array}$ & $\begin{array}{l}\text { Production tools and } \\
\text { Pure Factor of collective } \\
\text { independent }\end{array}$ & $\begin{array}{l}\text { Tools and Production facilitated by } \\
\text { state }\end{array}$ \\
\hline 3 & $\begin{array}{l}\text { Relations with the } \\
\text { State }\end{array}$ & $\begin{array}{l}\text { The relation is indepen- } \\
\text { dent }\end{array}$ & Dependent with the state \\
\hline 4 & $\begin{array}{l}\text { Economic develop- } \\
\text { ment }\end{array}$ & $\begin{array}{l}\text { Development is directed } \\
\text { at product diversification }\end{array}$ & $\begin{array}{l}\text { Development is directed at eco- } \\
\text { nomic growth by imitating Western } \\
\text { models }\end{array}$ \\
\hline 5 & $\begin{array}{l}\text { The position of } \\
\text { State and Society } \\
\text { Relations }\end{array}$ & $\begin{array}{l}\text { The Middle Class as a } \\
\text { mediator between the } \\
\text { State and Society }\end{array}$ & $\begin{array}{l}\text { The Middle Class as a state collabo- } \\
\text { rator }\end{array}$ \\
\hline
\end{tabular}

Source: compiled from various data

When referring to the comparative study presented at the tabulation above, several significant differences between the patterns of Western middle-class development with Third World Countries Intermediate class can be listed. However, it is important to remember that the middle class development in the third world is actually adopting a Western concept. However, instead of becoming middle class as expected in the West, it is directed to be a dependent society. Their disorientation to community development of middle class in third world countries itself is not separated from the patterns of patrimonialism which is still strong in the country and community relations. The state is still working to keep the loyalty of the middle class to sustain its power. Due to the growing middle class in the upbringing of capitalism, the middle class is not as independent as in the West. All the tools and factors of production have been facilitated by the state so as to make the middle class itself unable to move the economy in accordance with their respective creations.

However, the formation of the middle class in third world countries does not pass through a transition period like in West. However, the formation of the middle class in the case of the third world countries does not have a strong foundation of political economy. Middle class is not derived from the root of a strong bourgeoisie because their only background is agrarian root. The middle class also has no political position because it emphasizes the harmonization rather than establishing a relationship with the state opposition. In other words, the emergence of the middle class in the case of third world countries is the middle class that are "impromptu" and not equipped with sufficient capital capabilities. In the end, the middle class political position becomes diametrically between siding with the state and also favor of the interests of capital.

The emergence of the middle class in Indonesia in various academic discourses is more properly called as "group" rather than as "class". The preference of term "class", under the analysis of more Bulkin, is because the emergence of the middle class in Indonesia does not have the political power and independent attitude to the state, but it is growing in the care of the state. Indonesian society is actually a simple structure that only the king-servant that it actually indicates a top-down dichotomous relationship. In addition to the case of Bulkin analysis, the imposition of term class / group should also be related to the politicization of the New Order that middle group is part of the "work". This means that the new society is created by a regime focuses on economic development, but not development-ori- 
ented politics

That is actually the culture of Indonesian society that there is no initiation to transform the group from a pariah to the elite level. The existence of a strong culture of patronage that makes the class dichotomy is maintained to tie loyalty and legitimacy of power.

The condition reminds us that the presence of "new society" in Indonesia has a different character with other community groups. Those who are skilled in administrative matters such as intellectuals, tactical workers, and also the bourgeoisie are actually categorized as a new occupational groups in Indonesia that were previously relying on the agricultural sector. The emergence of the middle class in the history of Indonesia also marks the modernization of the structure of Indonesian society which is shown by the emergence of lifestyle as part of social capital and cultural capital. As described by Furnivall, the emergence of the middle class in Indonesia marks their community spirit of plural society living in harmony, but not be a as a political entity.

The analysis of the emergence of the middle class in Indonesia in the era of postcolonialism itself can be described into two forms namely embourgeoization and also proletarization. Both forms of analysis are part of a macro view of institutional perspective in seeing the middle class as part of the process of the establishment of the state and society relations. The first analysis of the embourgeoization is more directed to the entrepreneur class establishment by the government through a variety of economic stimulus. The analysis of the proletarization is more directed in the form of a ready-made and reliable job creation in order to support economic development. Two analyzes are essentially comes in response to developmental programs initiated by the New Order regime when in power.

However, the case with the political condition of the middle class when it is in a period of political independence revolution toward the socio-political development is different. At this developmental age, middle-class political conditions are in a state of subordination. The change of political side to be apolitical becomes a unique study of political studies of the Indonesian middle class. Some reviewers of political studies of the Indonesian middle class such as Howard Dick, Aswab Mahasin, Richard Robison, and also Robert Hefner view the transformation of the middle class in terms of Neo-Marxian and also structuralism. And the expert on the study of middle class such as Ariel Heryanto, Farchan Bulkin, and also Kenneth Young put their own middle-class development located in the outskirts of the capitalist perspective. As for the understanding of periphery capitalism (laissez-fraire capitalism), it is interesting to examine in studying the political developments of the Indonesian middle class. The term is initiated by Kunio Yosihiro in his book "Artificial Capitalism in Southeast Asia" to comparatively analyze the patterns of industrialization in the Southeast Asian country. This is important to address the analysis of capitalist relations in the Southeast Asian country in establishing and developing the industrialization and economic development autonomously and independently. The role of the state is getting bigger in the control of economic activity. This also applies in the form of the bourgeoisie as the backbone of the economy. In other words, the bourgeoisie is a motor forming a country's middle class politics. Therefore, the emergence of the middle class during the New Order Indonesia is sometimes called as the New Rich Group (OKB). The symptoms of new rich people is also struck in various parts of other Asian countries that show their massive economic growth

The establishment of the Indonesian middle class in the developmental era also follows the pattern similarity. However, the developments of the middle class in Indonesian case Indonesia thrive within the framework of the elite. It then puts the relationship in terms of the position of the middle class and elitist prismatic. The middle class cronies thrive within the framework of power. The influx of middle-class within the circle of power is part of the political corporatism establishment process run 
by the New Order government to bind the community loyalty. An important premise that needs to be recorded in analyzing floating mass policy that applies in Indonesian society. The emphasis of de-ideologization and de-politicization in the new society is what creates the presence of the Indonesian middle class.

However, what is interesting is the rise of Islamic political negotiations with the countries which later results in the face of the new middle class of Indonesian Mus$\mathrm{lim}$ as compared with the more common middle class. The emergence of the Muslim middle class is a form of oppression of the old regime which then undergoes revival during the New Order begins to slacken their power. However, the emergence of the spirit of militancy students as agents of change marks a new chapter in reading Indonesian middle class. It can be seen from the emergence of ICMI as a political mouthpiece of the Muslim middle class. In addition, the emergence of the PRD in 1996 is also impor- tant conclusion about the middle-class political activism which now begins to explore the underground movement action. The emergence of various movements marks the "radicalization" of political movements that are previously unheard of. The ideologies that frame the movement of the middle class are such as socialism, democracy, and also Islamism. The peak of the movement is when there was demonstrations in 1998 that dropped the New Order regime. This was actually a part of the political synergy.

Today's post-authoritarian politics even leads the middle class of Indonesia to fluctuating position for a political movement. In general, the political movement of middle-class that occurs during reformation experienced significant turbulence depending on the context and the events that followed. However, the emergence of social media as a representation platform becomes an important point in forming a channel of political representation for the middle class.

Table 4.

\begin{tabular}{|c|c|c|c|c|}
\hline & $\begin{array}{c}\text { Political Base Phase } \\
\text { of Indonesian } \\
\text { Middle Class }\end{array}$ & $\begin{array}{l}\text { Parameter of } \\
\text { Political Base }\end{array}$ & $\begin{array}{l}\text { Political ide- } \\
\text { ology }\end{array}$ & Middle Class Actors \\
\hline 1 & $\begin{array}{l}\text { Indonesian Middle } \\
\text { Class of } 1920 \text { until } \\
1965\end{array}$ & $\begin{array}{l}\text { - Political Activ- } \\
\text { ism } \\
\text { - Resistance } \\
\text { - Political cam- } \\
\text { paign } \\
\text { - articulation } \\
\text { Interests }\end{array}$ & $\begin{array}{l}\text { - Liberalism } \\
\text { - Socialism } \\
\text { - Communism } \\
\text { - Nationalism }\end{array}$ & $\begin{array}{ll}\text { - } & \text { Community organi- } \\
& \text { zation } \\
\text { - } & \text { Bureaucracy } \\
\text { - } & \text { College student } \\
\text { - } & \text { Press } \\
\text { - Political parties } \\
\text { - College intellectual }\end{array}$ \\
\hline 2 & $\begin{array}{l}\text { Indonesian Middle } \\
\text { Class of } 1965 \text { until } \\
1998\end{array}$ & $\begin{array}{l}\text { - Political apathy } \\
\text { - Political corpo- } \\
\text { ratism } \\
\text { - Underground } \\
\text { Political Move- } \\
\text { ment } \\
\text { - dissemination } \\
\text { idea } \\
\text { - Democracy }\end{array}$ & $\begin{array}{l}\text { - Liberalism } \\
\text { - Socialism } \\
\text { - Islamism } \\
\text { - Democracy }\end{array}$ & $\begin{array}{l}\text { - Democracy Activist } \\
\text { - College student } \\
\text { - College intellectual } \\
\text { - Bourgeoisie } \\
\text { - Bureaucracy }\end{array}$ \\
\hline 3 & $\begin{array}{l}\text { Indonesian Middle } \\
\text { Class of } 1998 \text { until } \\
\text { now }\end{array}$ & $\begin{array}{l}\text { - Online activ- } \\
\text { ism via Social } \\
\text { Media }\end{array}$ & $\begin{array}{l}\text { - Liberalism } \\
\text { - Democracy } \\
\text { - Socialism }\end{array}$ & $\begin{array}{l}\text { - Young executive } \\
\text { - College student } \\
\text { - Bureaucracy } \\
\text { - Housewife } \\
\text { - Bourgeoisie }\end{array}$ \\
\hline
\end{tabular}

Source: compiled from various data 
To read the political analysis of the Indonesian middle class, it is important to look at several variables such as the context of events, ideologies, and also actors who play a role and also become important motor. It is also noted that since the emergence of the Indonesian middle class politics that began in 1920 with their ethical politics until now, they show the characteristics of the Indonesian middle class which is different. Hence, for more details, the division of the political base of the Indonesian middle class can be described in the following table.

Toward a wide range of parameters, an outline of the Indonesian middle class political experiences various uniquely political turbulences. At the initial appearance, the Indonesian middle class is able to appear as an active political movement. However, over time, the Indonesian middle class political position is always fluctuating. Another thing to note is the political basis of the media movement. As it can be drawn from the tabulation, the content of political aspiration which was originally based on demonstration and also a political message now begins to explore the social media. But the critical question that needs to be disclosed is how effective social media has become a tool of the political representation.

\section{CONCLUSION}

The discussion of the Indonesian middle class politics is directed to its form of content and context. In its content, the portrait of the Indonesian middle class actually has a fluctuating society basis. As a new social class in the hierarchy of society, the middle class of Indonesia does not have a strong base of mass and the media is rather intermediary. This is because the Indonesian middle class society is formed by the state and always follows the country so it is not grounded in the community. And in the context of Indonesian middle class, they show their existence as elitist and legitimize themselves as a different class to the community.
The pattern of development of the middle class, basically follow the linear pattern of middle-class development located in the Asian region with symptoms of booming post the high economic growth. However, the Indonesian middle class is expected to become an economic powerhouse. In fact, the middle class of Indonesia is hoped to be the host in the country.

However, behind the public skepticism, the political potential addressed by the Indonesian middle class is actually high. This can be seen from a variety of political activism both committed openly or clandestinely. In other words, the Indonesian middle class is actually a political literacy class, but it depends on the figures and events which follow them. Especially with the advance of social media and internet, they are at least expected to be able to build their strong political representation channels and to articulate their interests.

In the future, the role of the Indonesian middle class will play a significant role in the political reality of Indonesia both as a group and also the interests of pressure groups. It depends on how far the political activism and also criticism of the middle class in any advocacy of interests that is fought for.

\section{REFERENCES}

Chen, J., \& Lu, C., 2011. Democratization and the middle Class in China: The Middle Class's Attitudes Toward Democracy. Political Research Quarterly, 64(3), pp.705-719.

Chilcote, R., Theories of Comparative Politics: The Search for a Paradigm Reconsidered. Westview Press, Colorado.

Dursun, G., "Revisiting Karl Polanyi’s Transforming Market Society and Embedness Thesis" dalam Yildzi, Hirlal. 2015. Globalization Dimensions E Impacts: Global Studies Vol. 2. Istanbul: IJOPEC Publication.

Fereirra, F. et.al. 2012. Economic Mobility and the Rise of the Latin American Middle Class. Washington D.C

Firman, T., 2009. The Continuity and Change in Mega-Urbanization in Indonesia: A Survey of Jakarta-Bandung Region (JBR) development. Habitat International, 33(4), pp.327-339.

Gerke, S., 20oo. Global Lifestyles Under Local Conditions: The New Indonesian Middle Class. Consumption in Asia: Lifestyles and identities, 135. 
Hadiz, V.R., \& Robison, R., 2013. The political Economy of Oligarchy and the Reorganization of Power in Indonesia. Indonesia, 96(1), pp.35-57.

Hasan, N., 2009. The Making of Public Islam: Piety, Agency, and Commodification on the Landscape of the Indonesian Public Sphere. Contemporary Islam, 3(3), pp.229.

Heriyati, P., \& Siek, T.P., 2011. Effects of Word of Mouth Communication and Perceived Quality on Decision Making Moderated by Gender: Jakarta Blackberry Smartphone Consumer's Perspective. Contemporary Management Research, 7(4), p.329.

Heryanto, A., 2011. The New Middle Class and Islam in Indonesian Popular Culture. Islam and Popular Culture in Indonesia and Malaysia, pp.6o82.

Hoesterey, J.B., \& Clark, M., 2012. Film Islami: Gender, Piety and Pop Culture in Post-Authoritarian Indonesia. Asian Studies Review, 36(2), pp.207-226.

Jones, C., 2010. Materializing Piety: Gendered Anxieties about Faithful Consumption in Contemporary Urban Indonesia. American Ethnologist, 37(4), pp.617-637.

Kivinen, M., 1990. Analytical Marxism and Class Theory" in Clegg, Stewart (ed.) Organization Theory and Class Analysis. Walter de Gruyter, New York.

Luvaas, B., 2009. Dislocating Sounds: The Deterritorialization of Indonesian Indie Pop. Cultural Anthropology, 24(2), pp.246-279.

Luvaas, B., 2010. Designer Vandalism: Indonesian Indie Fashion and the Cultural Practice of
Cut'n'Paste. Visual Anthropology Review, 26(1), pp.1-16.

Mas'oed, M., 2006. Negara, Kapital, Demokrasi. Pustaka Pelajar, Yogyakarta.

Naafs, S., \& White, B., 2012. Intermediate Generations: Reflections on Indonesian Youth Studies. The Asia Pacific Journal of Anthropology, 13(1), pp.3-20.

Nilan, P., 2009. Contemporary Masculinities and Young Men in Indonesia. Indonesia and the Malay World, 37(109), pp.327-344.

Pepinsky, T.B., Liddle, R.W., \& Mujani, S., 2012. Testing Islam's Political Advantage: Evidence from Indonesia. American Journal of Political Science, 56(3), pp.584-6oo.

Poulantzas, N., 1975. Classes in Contemporary Capitalism. Verso, London.

Poulantzas, N., 1975. Political Power in Social Classes. Verso, London.

Rinaldo, R., 2010. . The Islamic Revival and Women's Political Subjectivity in Indonesia. In Women's Studies International Forum, 33(4), pp.422431.

Slama, M., 2010. The Agency of the Heart: Internet Chatting as Youth Culture in Indonesia. Social Anthropology, 18(3), pp.316-330.

Smith-Hefner, N.J., 2007. Youth Language, Gaul Sociability, and the NEW INDONESIAN MIDDLE CLASS. Journal of Linguistic Anthropology, 17(2), pp.184-203.

Standing, G., 2011. The Precariat: The New Dangerous Class. Bloomsbury Academic, London.

Wright, E.O., 2009. Understanding Class. New Left Review, 6o, pp.106-116 